\title{
The Rituximab Biosimilar CT-P10 in Rheumatology and Cancer: A Budget Impact Analysis in 28 European Countries
}

László Gulácsi • Valentin Brodszky · Petra Baji · Fanni Rencz •

Márta Péntek

Received: March 3, 2017 / Published online: April 10, 2017

(C) The Author(s) 2017. This article is an open access publication

\section{ABSTRACT}

Introduction: New biosimilars of monoclonal antibodies are anticipated to bring significant cost savings and increase access to treatment. The rituximab biosimilar CT-P10 has recently been approved in Europe in all indications held by reference rituximab (RTX), including rheumatoid arthritis, non-Hodgkin's lymphoma, and chronic lymphocytic leukemia. We analyzed the budgetary impact of the introduction of CT-P10 into the European Union (EU) for use in patients with rheumatoid arthritis and cancer diagnoses, using a budget impact analysis model.

Methods: The model used a base case scenario in which the 1-year uptake of CT-P10 was estimated at $30 \%$, and the cost of CT-P10 was

Enhanced Content To view enhanced content for this article go to http://www.medengine.com/Redeem/ C608F06060E1A88B.

Electronic supplementary material The online version of this article (doi:10.1007/s12325-017-0522-y) contains supplementary material, which is available to authorized users.

L. Gulácsi $(\bowtie) \cdot$ V. Brodszky · P. Baji · F. Rencz · M. Péntek

Corvinus University of Budapest and HTA

Consulting Budapest, Budapest, Hungary

e-mail: laszlo.gulacsi@uni-corvinus.hu

M. Péntek

Flór Ferenc County Hospital, Kistarcsa, Hungary assumed to be $70 \%$ of the cost of RTX. A second 1-year scenario was also modeled, in which the market share of CT-P10 was assumed to be 50\% (scenario 2). Finally, 3-year time horizon outcomes were calculated, in which the market share of CT-P10 was assumed to be 30\%, 40\%, and $50 \%$ in the first, second, and third years, respectively.

Results: In the base case scenario, the introduction of CT-P10 was associated with projected savings of $€ 90.04$ million in the first year, which would allow 7531 additional patients to access rituximab treatment. This was equivalent to a $6.4 \%$ increase in the number of rituximab-treated patients. In scenario 2, budget savings were $€ 150.10$ million, with a total of 12,551 additional patients able to access rituximab, equivalent to a $10.7 \%$ increase. Over a 3-year time horizon, projected budget savings were approximately $€ 570$ million, equating to 47,695 additional patients able to access rituximab.

Conclusions: The model predicted that the introduction of CT-P10 in the EU will be associated with significant budget savings, the reallocation of which will enable many more patients to access rituximab treatment. This is likely to have a significant impact on health gains at patient and societal levels.

Funding: CELLTRION Healthcare Co., Ltd. sponsored the development and analysis of the budget impact analysis model. 
Keywords: Biosimilar; Budget impact analysis; Chronic lymphocytic leukemia; CT-P10; Non-Hodgkin's lymphoma; Rheumatoid arthritis; Rheumatology; Rituximab

\section{INTRODUCTION}

Rituximab was the first monoclonal antibody to be approved for the treatment of cancer and is also approved in the treatment of rheumatoid arthritis (RA) (as MabThera ${ }^{\circledR}$ [Roche] in Europe and Rituxan ${ }^{\circledR}$ [Biogen/Genentech] in the USA) $[1,2]$. As this anti-CD20 monoclonal antibody has now reached patent expiration, biosimilar versions are in development. One such agent, CT-P10, has recently been approved in Europe for all indications held by MabThera ${ }^{\circledR}$ (or "reference rituximab", hereafter abbreviated as RTX) [3]. As such, CT-P10 is the first biosimilar of a monoclonal antibody to be approved in any cancer indication.

The European Medicines Agency (EMA) defines a biosimilar as a product that is similar to a biological medicine that has already been authorized, the so-called reference product. A similar biological product and its reference product are expected to have the same safety and efficacy profile and are generally used to treat the same conditions [4]. Biosimilars of first-generation biological products (termed "first-generation biosimilars"), including granulocyte-colony stimulating factor and erythropoietin [5], have been available for some time in the field of supportive cancer care [6]. More recently, biosimilars of more complex, second-generation biologicals such as monoclonal antibodies ("second-generation biosimilars") [5], have been approved in RA and other immune-related inflammatory diseases (e.g., the infliximab biosimilars CT-P13 [Remsima $^{\circledR}$, Celltrion], Flixabi ${ }^{\circledR}$ [Samsung Bioepis], and Inflectra ${ }^{\circledR}$ [Hospira], and the etanercept biosimilar Benepali ${ }^{\circledR}$ [Samsung Bioepis]) [6].

RTX is indicated in the treatment of RA, non-Hodgkin's lymphoma (NHL), chronic lymphocytic leukemia (CLL), granulomatosis with polyangiitis (formerly Wegener's granulomatosis), and microscopic polyangiitis $[1,2]$. It is also used off-label in systemic lupus erythematosus, multiple sclerosis, and neuromyelitis optica spectrum disorders [7-11]. In this study of the budget impact of the introduction of CT-P10 into the European Union (EU), we focus primarily on RA, NHL (diffuse large B cell lymphoma [DLBCL] and follicular lymphoma [FL]), and CLL. All of these diseases have significant financial impacts on global healthcare systems. For example, RA is a chronic, progressive disease associated with significant direct and indirect costs to society $[12,13]$. As the population ages, RA becomes an increasing burden globally. RA was the 42nd highest contributor to global disability in 2010, with RA-associated disability-adjusted life years increasing markedly in recent years [14]. Lymphoma incidence has also increased substantially in recent decades, with 666,000 cases of NHL reported globally in 2015 [15]. The growing incidence of lymphoma, along with its increasing prevalence due to improvements in treatment, has led to a marked rise in the number of patients requiring treatment $[15,16]$. CLL is the most common leukemia in the Western world [17], with 191,000 cases globally in 2015 [15] and its incidence continuing to rise [18]. The incidence of CLL increases with age [17], making this another disorder of growing importance in an aging population. Over the last 15 years the treatment of $\mathrm{CD} 20+$ cancers has been revolutionized owing to the introduction of anti-CD20 monoclonal antibodies, primarily RTX $[19,20]$. Biological disease-modifying antirheumatic drugs have similarly advanced the treatment of RA [21], with RTX an important therapeutic intervention for patients in whom anti-tumor necrosis factor therapy has failed [13]. Accordingly, RTX is recognized as an important treatment option in European clinical guidelines in both cancer and rheumatology [13, 17, 21-26].

Despite this, the impact of biological therapies is often diminished in clinical practice by inequalities in patient access, with budget constraints and cost-related barriers a key factor [27-30]. The advent of second-generation biosimilars therefore represents an opportunity to improve patient access to biologicals. This is reflected in a recent position paper from the European Society for Medical Oncology, which recognizes that biosimilars can improve the financial sustainability of healthcare systems and thus meet an important need globally [31]. 
Expenditure forecast modeling in the EU predicts that a wider availability of biosimilars would be associated with decreased spending on medications [32] and that the availability of biosimilars will be a driving force for budgetary savings [33].

Budget impact analysis (BIA) models estimate the expected changes in expenditure that would occur as a result of the adoption of a new therapeutic intervention. As such, BIAs provide valuable information, alongside cost-effectiveness analyses, for budget planning and resource allocation [34], and are increasingly required by payers [35]. In addition to calculating potential cost savings, a BIA model also estimates the impact of such cost savings on patient access to treatment. At present, there is a lack of published BIA models evaluating the impact of second-generation biosimilars [34].

The aim of our study was to analyze the budgetary impact of the introduction of CT-P10 into 28 European countries, in RA and cancer, using a BIA model. Owing to the biosimilarity of RTX and CT-P10, as evidenced in non-clinical evaluations and randomized controlled trials in RA [36-43] and FL [44, 45], we hypothesized that the introduction of CT-P10 would be associated with budget savings and a subsequent increase in the number of patients able to access rituximab treatment.

\section{METHODS}

A Microsoft Excel-based budget impact model was developed to estimate the cost savings achievable with the introduction of CT-P10. A budget impact model for the introduction of CT-P10 in 28 European countries was developed over a 1-year time horizon as a base case scenario. Three-year time horizon outcomes were also calculated. The model considered use in all indications (RA, DBLCL, FL, CLL, granulomatosis with polyangiitis, and microscopic polyangiitis), as well as off-label use, in the 28 EU member states. Further analyses then focused on projected budget savings and subsequent potential increases in patients with access to rituximab treatment, in RA, DLBCL, FL, and CLL. The model was developed according to the recommendations proposed by the International Society for Pharmacoeconomics and Outcomes Research's principles of good practice for BIAs [35].

\section{Patient Population}

The initial number of patients treated with RTX was estimated on the basis of IMS sales data (total annual consumption of RTX [MabThera ${ }^{\circledR}$ ] in milligrams), thereby reflecting real-life utilization. IMS data are not split according to the indications/diagnoses in which RTX is used, rather data are provided for the total consumption per country. Thus, we estimated the initial number of patients with each diagnosis of interest based on literature data and expert assumptions. The estimation process is described in detail in Fig. 1; assumptions and model parameters are summarized in Supplementary Table S1. We assumed that $10 \%$ of the total consumption was accounted for by the EMA-registered indications granulomatosis with polyangiitis and microscopic polyangiitis, as well as off-label use in systemic lupus erythematosus, multiple sclerosis, and neuromyelitis optica spectrum disorders. Of the remaining consumption ( $90 \%$ of total), $20 \%$ was attributed to use in RA and $80 \%$ to the three cancer diagnoses [46]. Among the cancer diagnoses (DLBCL, newly diagnosed FL patients, relapsed/ refractory FL patients, and CLL) consumption per diagnosis was estimated on the basis of the total annual dose (in milligrams) per patient (see Table 1) and the incidence of the given diagnosis (Supplementary Table S1).

Weightings were calculated according to the formula in Fig. 1.

Crude incidence rates were obtained from the HAEMACARE project, which studied over 66,000 patients with lymphoid malignancies registered in a total of 44 large European registries. HAEMACARE is a European cancer registry-based project funded by the European Commission. The project reported data on the incidence of hematological malignancies (from 2000 to 2002) from cancer registries in 17 countries. In DLBCL, FL, and CLL, all case incidence rates per 100,000 population were 3.81 (95\% confidence interval 3.73-3.89), 2.18 


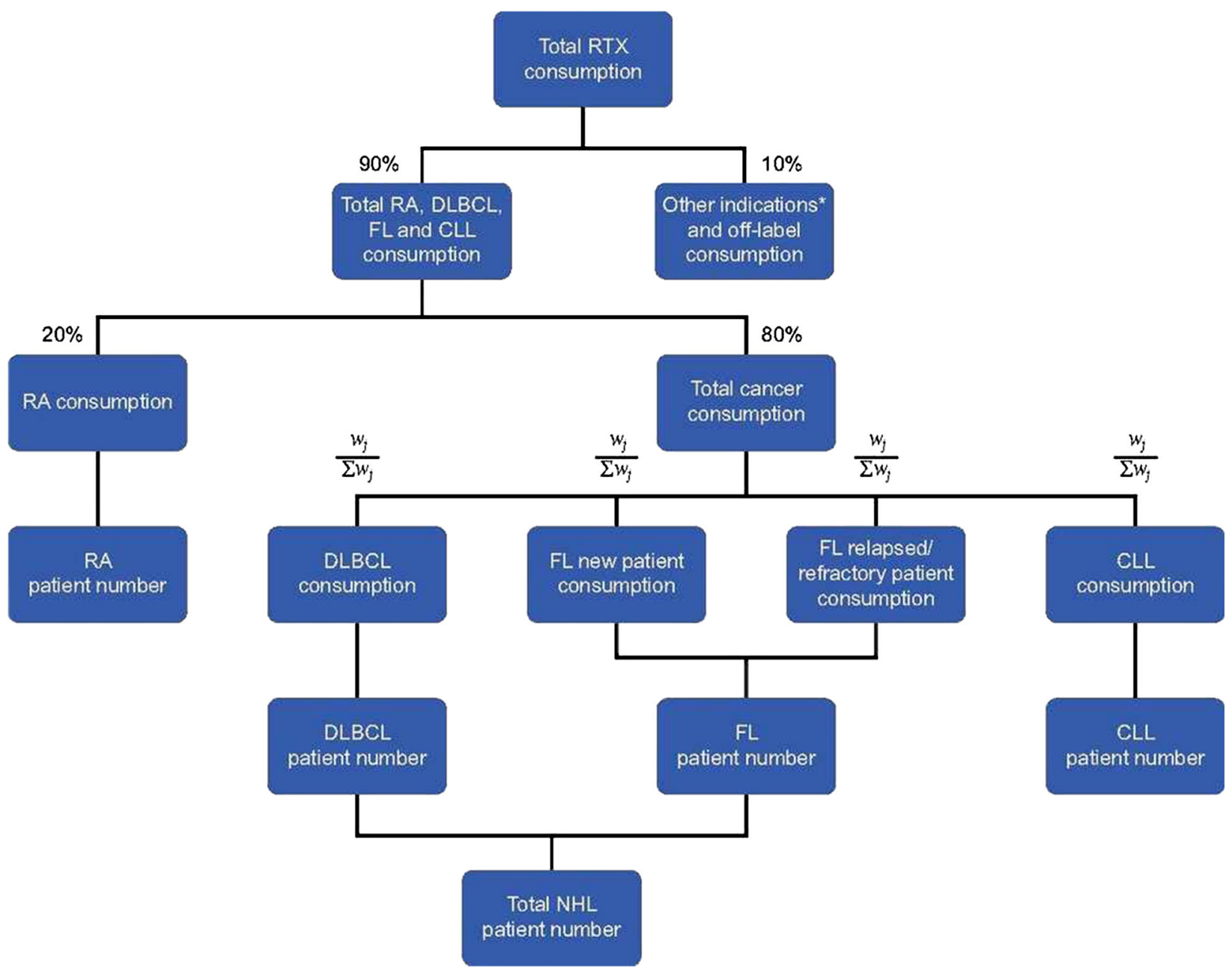

Fig. 1 Budget impact analysis estimation methodology. $C L L$ chronic lymphocytic leukemia, $D L B C L$ diffuse large $\mathrm{B}$ cell lymphoma, $F L$ follicular lymphoma, $N H L$ non-Hodgkin's lymphoma, $R A$ rheumatoid arthritis, $R T X$ reference rituximab. *Granulomatosis with polyangiitis (formerly Wegener's granulomatosis) and microscopic polyangiitis. Weightings were calculated according to the formula $\frac{w_{j}}{\sum_{j=1}^{4} w_{j}}=$ $\frac{\text { incidence }_{j} \times \text { consumption__per_year }{ }_{j} \times \text { rituximab_treatment_rate }_{j}}{\sum_{j=1}^{4} \text { incidence }_{j} \times \text { consumption_per_year }_{j} \times \text { rituximab_treatment_rate }_{j}}$ where

(2.12-2.24), and 4.92 (4.83-5.01), respectively [47]. To calculate weightings in our model, we assumed that

- The percentage of incident patients treated with RTX was 95\% for DLBCL [48, 49], 80\% for FL [50], and 78\% for CLL [51].

- $80 \%$ of FL patients go through maintenance therapy [52]. incidence $_{j}$ is the crude incidence rate of indication $j$ (Supplementary Table S1), consumption_per_year ${ }_{j}$ is the total need (in milligrams) of rituximab to treat indication $j$ (Table 1), and rtx_treatment_rate ${ }_{j}$ is the proportion of patients in indication $j$ treated with rituximab (Supplementary Table S1).

- Retreatment rate in FL is $20 \%$ (based on authors' expert opinions).

IMS data were not available in eight countries. Therefore, in each case, data from a neighboring country with a similar level of economic development were applied (e.g., data from Denmark were applied to Sweden, data from Spain were applied to Greece) in order to 
Table 1 Reference rituximab doses and consumption for induction and maintenance treatment in various indications

\begin{tabular}{|c|c|c|c|}
\hline Diagnosis & Induction dose & Maintenance dose & $\begin{array}{l}\text { Total RTX } \\
\text { consumption per } \\
\text { patient (mg) }\end{array}$ \\
\hline RA & - & $2 \times 1000 \mathrm{mg} / 6$ months & 4000.00 \\
\hline DLBCL & $\begin{array}{l}375 \mathrm{mg} / \mathrm{m}^{2} \text { per cycle, } \\
\text { for up to } 8 \text { cycles }\end{array}$ & - & 5370.00 \\
\hline \multicolumn{4}{|l|}{ FL } \\
\hline Newly diagnosed & $\begin{array}{l}375 \mathrm{mg} / \mathrm{m}^{2} \text { per cycle, } \\
\text { for up to } 8 \text { cycles }\end{array}$ & $\begin{array}{l}375 \mathrm{mg} / \mathrm{m}^{2} \text { every } 2 \text { months (starting } 2 \text { months after the } \\
\text { last dose of induction therapy), until disease } \\
\text { progression or for a maximum period of } 2 \text { years }\end{array}$ & 1814.00 \\
\hline $\begin{array}{l}\text { Relapsed/ } \\
\text { refractory }\end{array}$ & $\begin{array}{l}375 \mathrm{mg} / \mathrm{m}^{2} \text { per cycle, } \\
\text { for up to } 8 \text { cycles }\end{array}$ & $\begin{array}{l}375 \mathrm{mg} / \mathrm{m}^{2} \text { once every } 3 \text { months (starting } 3 \text { months after } \\
\text { the last dose of induction therapy), until disease } \\
\text { progression or for a maximum period of } 2 \text { years }\end{array}$ & 1933.20 \\
\hline CLL & - & $1 \times 375 \mathrm{mg} / \mathrm{m}^{2}+5 \times 500 \mathrm{mg} / \mathrm{m}^{2}$ & 5146.25 \\
\hline
\end{tabular}

Mean body surface area was set at $1.79 \mathrm{~m}^{2}$ according to a retrospective analysis of over 3500 patients receiving chemotherapy treatment at three oncology centers in the UK [54]

$C L L$ chronic lymphocytic leukemia, $D L B C L$ diffuse large B cell lymphoma, $F L$ follicular lymphoma, $R A$ rheumatoid arthritis, $R T X$ reference rituximab

estimate annual RTX consumption. Estimates were based on IMS data for the consumption (in milligrams) per capita.

For all diagnoses, a fixed cohort of patients was analyzed over a 1-year and 3-year time horizon. The number of patients receiving either RTX or CT-P10 was calculated according to the market uptake assumptions made. RTX-naïve and switch (i.e., patients already receiving RTX who were switched to CT-P10) patient groups were not distinguished. The total number of patients $(P)$ treated with rituximab was defined as the sum of patients treated with RTX and CT-P10:

$$
P=P_{\mathrm{RTX}}+P_{\mathrm{CT}-\mathrm{P} 10}
$$

The total number of patients was assumed to remain the same over the time horizon analyzed, with any treatment discontinuation offset by new patients initiating treatment.

\section{Uptake of CT-P10}

The uptake of CT-P10 (expressed as the proportion of patients receiving CT-P10 who would otherwise have received RTX) was estimated at $30 \%$ over a 1-year time horizon in all diagnoses as a base case scenario.

\section{Costs}

The model applied a third-party payer's perspective, and only direct drug costs were included. Actual purchasing prices of RTX are not publicly available and can vary even within country because of local tenders and other managed entry agreement financial mechanisms [53]. Thus, official list prices of RTX were used in the model (Table 2 and Supplementary Table S2). The list price of CT-P10 was not known at the time of the analysis and thus we assumed it to be $70 \%$ of the RTX price. This discount was tested in the sensitivity analysis.

Annual costs of patients receiving RTX and CT-P10 were computed on the basis of the cost and the dose (in milligrams) of drugs required in each diagnosis per year. In the case of RA, we applied the price of 500-mg vials, while for all other diagnoses an average price per milligram 
Table 2 Official list prices of MabThera ${ }^{\circledR}$ in national currencies

\begin{tabular}{|c|c|c|c|}
\hline Country & Currency & MabThera $^{\circledR}(2 \times 100 \mathrm{mg})$ & MabThera $^{\circledR}(500 \mathrm{mg})$ \\
\hline Austria & EUR & 899.00 & 2158.35 \\
\hline Belgium & EUR & 410.76 & 1035.79 \\
\hline Bulgaria & BGN & 1013.45 & 2484.47 \\
\hline Croatia & HRK & 3755.49 & 9220.34 \\
\hline Cyprus & EUR & 662.35 & 1624.52 \\
\hline Czech Republic & CZK & $11,427.77$ & $28,707.57$ \\
\hline Denmark & DKK & 5188.15 & $12,943.30$ \\
\hline Estonia & EUR & 642.42 & 1606.03 \\
\hline Finland & EUR & 708.26 & 1966.31 \\
\hline France & EUR & 474.61 & 1186.52 \\
\hline Germany & EUR & 840.19 & 2044.49 \\
\hline Greece & EUR & 418.49 & 1050.02 \\
\hline Hungary & HUF & 145,081 & 361,207 \\
\hline Ireland & EUR & 507.25 & 1266.09 \\
\hline Italy & EUR & 870.48 & 2175.78 \\
\hline Latvia & EUR & 441.50 & 1102 \\
\hline Lithuania & EUR & 731.81 & 1719.71 \\
\hline Luxemburg & EUR & 420.90 & 1061.37 \\
\hline Malta & EUR & 750 & 1380 \\
\hline Netherlands & EUR & 554.91 & 1387.29 \\
\hline Poland & PLN & 2445.01 & 6112.52 \\
\hline Portugal & EUR & 457.62 & 1138.93 \\
\hline Romania & RON & 2221.55 & 5509.03 \\
\hline Slovakia & EUR & 494.36 & 1226.16 \\
\hline Slovenia & EUR & 577.03 & 1442.64 \\
\hline Spain & EUR & 567.93 & 1342.06 \\
\hline Sweden & SVK & 3787 & 9468 \\
\hline UK & GBP & 349.26 & 873.15 \\
\hline
\end{tabular}

See Supplementary Table S2 for sources 
of RTX was calculated on the basis of the list price of $100-\mathrm{mg}$ and $500-\mathrm{mg}$ vials in each country. Calculations are as follows:

$$
\begin{aligned}
\operatorname{Cost}_{\mathrm{RTX}_{i j}} & =\sum_{i=1}^{28} \sum_{j=1}^{4} c_{\mathrm{mgRTX}_{i}} \times \mathrm{d} j \\
\operatorname{Cost}_{\mathrm{CT}-\mathrm{P} 10_{i j}} & =\sum_{i=1}^{28} \sum_{j=1}^{4} c_{{\mathrm{mgCT}-\mathrm{P} 10_{i}}_{i} \times \mathrm{d} j}
\end{aligned}
$$

where $i$ is the country selected in the model (maximum of 28), $j$ is the indication selected in the model (maximum of 4: RA, NHL, CLL, and "other", including off-label use), $c_{\text {mgMabThera }_{i}}$ is cost per $1 \mathrm{mg}$ of MabThera in country $i$, $c_{\mathrm{mgCT}-\mathrm{P} 10_{i}}$ is cost per $1-\mathrm{mg}$ vial of CT-P10 in country $i$, and $\mathrm{d} j$ is the total number of doses required per year in indication $j$.

Mean body surface area (BSA) was set at $1.79 \mathrm{~m}^{2}$, in line with literature data from a retrospective analysis of over 3500 adult patients receiving chemotherapy treatment at three oncology centers in the UK [54]. In the three cancer diagnoses, the total dose (in milligrams) per diagnosis was calculated by multiplying the mean BSA $\left(1.79 \mathrm{~m}^{2}\right)$ of a patient with the dose required in indication $j$ (Table 1). For induction therapy, the total number of doses required annually for indication $j\left(d_{j}\right)$ was available from treatment guidelines and the RTX summary of product characteristics $[1,17,55,56]$ (Table 1$)$. For maintenance therapy, the total number of doses required annually for indication $j$ was determined according to the following formula:

$$
\mathrm{d}_{j}=\frac{52}{\text { number of weeks betweeen maintenance doses }}
$$

We did not include administration and monitoring costs in the calculations, since we assumed these to be equal for RTX and CT-P10; thus no budget impact is implied.

\section{Budget Impact}

Total budget impact of the introduction of CT-P10 into the treatment of indication $j$ in country $i$ was estimated as follows:

$$
\begin{aligned}
\theta_{\mathrm{CT}-\mathrm{P} 10}= & \mathrm{P} \times \text { Cost }_{\mathrm{RTX}} \\
& -\left(\mathrm{P}_{\mathrm{RTX}} \times \text { Cost }_{\mathrm{RTX}}+\mathrm{P}_{\mathrm{CT}-\mathrm{P} 10} \times \text { Cost }_{\mathrm{CT}-\mathrm{P} 10}\right)
\end{aligned}
$$

The number of new patients that could be treated from the budget savings was also calculated for each diagnosis. It was assumed that budget savings from the treatment of each diagnosis were reallocated to increase patient access within the same diagnosis (e.g., that any savings made in the treatment of RA were used to treat additional RA patients with biosimilar rituximab).

\section{Sensitivity Analysis}

One-way sensitivity analyses were carried out to test the robustness of the model assumptions. The following model parameters were varied by $\pm 10 \%$ : the discount on the price of CT-P10, market uptake of CT-P10, total number of patients treated with rituximab, and average BSA.

\section{Compliance with Ethics Guidelines}

This article does not contain any new studies with human or animal subjects performed by any of the authors.

\section{RESULTS}

\section{One-Year Time Horizon}

Assuming that the price of CT-P10 was 70\% of the price of RTX and that the CT-P10 market share was 30\% (base case scenario), the total projected budget saving in Europe was $€ 90.04$ million (of which $26.9 \%$ was saved in the treatment of RA, $43.3 \%$ in the treatment of NHL (DLBCL and FL), $19.8 \%$ in the treatment of CLL, and $10.0 \%$ in the treatment of other diagnoses). Seventy percent of the total budget savings were realized in five European countries, namely Germany $(22.8 \%)$, Italy $(17.7 \%)$, France $(13.5 \%)$, Spain $(8.4 \%)$, and the UK (7.5\%) (Table 3).

Projected budget savings would permit access to rituximab therapy for 7531 additional patients (including 2857 patients with RA, 2263 
Table 3 Projected budget impact (savings) over 1 year due to the introduction of CT-P10, and the number of additional patients that could subsequently gain access to rituximab treatment (base case scenario)

\begin{tabular}{|c|c|c|c|c|c|c|c|c|c|c|}
\hline & \multicolumn{2}{|l|}{$\mathbf{R A}$} & \multicolumn{2}{|l|}{$\mathrm{NHL}^{\mathrm{a}}$} & \multicolumn{2}{|l|}{ CLL } & \multicolumn{2}{|c|}{$\begin{array}{l}\text { Other indications } \\
\text { and off-label use }\end{array}$} & \multicolumn{2}{|l|}{ Total $^{c}$} \\
\hline & $\begin{array}{l}\text { Budget } \\
\text { impact, } \\
\text { million } \\
\text { EUR }\end{array}$ & $\begin{array}{l}\text { No. of } \\
\text { patients }\end{array}$ & $\begin{array}{l}\text { Budget } \\
\text { impact, } \\
\text { million } \\
\text { EUR }\end{array}$ & $\begin{array}{l}\text { No. of } \\
\text { patients }\end{array}$ & $\begin{array}{l}\text { Budget } \\
\text { impact, } \\
\text { million } \\
\text { EUR }\end{array}$ & $\begin{array}{l}\text { No. of } \\
\text { patients }\end{array}$ & $\begin{array}{l}\text { Budget } \\
\text { impact, } \\
\text { million } \\
\text { EUR }\end{array}$ & $\begin{array}{l}\text { No. of } \\
\text { patients }\end{array}$ & $\begin{array}{l}\text { Budget } \\
\text { impact, } \\
\text { million } \\
\text { EUR }\end{array}$ & $\begin{array}{l}\text { No. of } \\
\text { patients }\end{array}$ \\
\hline Austria & -0.89 & 73 & -1.45 & 58 & -0.66 & 42 & -0.33 & 20 & -3.33 & 193 \\
\hline Belgium & -0.36 & 63 & -0.58 & 50 & -0.26 & 36 & -0.13 & 17 & -1.34 & 165 \\
\hline Bulgaria & -0.14 & 19 & -0.22 & 15 & -0.10 & 11 & -0.05 & 5 & -0.51 & 50 \\
\hline Croatia & -0.13 & 20 & -0.22 & 16 & -0.10 & 11 & -0.05 & 5 & -0.50 & 52 \\
\hline $\begin{array}{l}\text { Czech } \\
\text { Republic }\end{array}$ & -0.11 & 18 & -0.17 & 14 & -0.08 & 10 & -0.04 & 5 & -0.40 & 47 \\
\hline Finland & -0.70 & 64 & -1.07 & 50 & -0.49 & 36 & -0.25 & 18 & -2.51 & 168 \\
\hline France & -3.29 & 496 & -5.28 & 392 & -2.41 & 282 & -1.22 & 137 & -12.19 & 1306 \\
\hline Germany & -5.49 & 479 & -8.91 & 379 & -4.06 & 272 & -2.05 & 132 & -20.51 & 1262 \\
\hline Hungary & -0.23 & 35 & -0.37 & 28 & -0.17 & 20 & -0.09 & 10 & -0.85 & 92 \\
\hline Ireland & -0.26 & 37 & -0.42 & 29 & -0.19 & 21 & -0.10 & 10 & -0.96 & 96 \\
\hline Italy & -4.31 & 354 & -6.90 & 280 & -3.15 & 201 & -1.60 & 98 & -15.96 & 932 \\
\hline Netherlands & -0.81 & 105 & -1.30 & 83 & -0.59 & 59 & -0.30 & 29 & -3.01 & 276 \\
\hline Poland & -1.09 & 140 & -1.75 & 111 & -0.80 & 79 & -0.40 & 38 & -4.04 & 368 \\
\hline Portugal & -0.17 & 26 & -0.27 & 21 & -0.12 & 15 & -0.06 & 7 & -0.62 & 69 \\
\hline Romania & -0.31 & 45 & -0.50 & 36 & -0.23 & 26 & -0.11 & 12 & -1.15 & 119 \\
\hline Slovakia & -0.18 & 27 & -0.29 & 21 & -0.13 & 15 & -0.07 & 7 & -0.68 & 70 \\
\hline Slovenia & -0.11 & 14 & -0.18 & 11 & -0.08 & 8 & -0.04 & 4 & -0.41 & 36 \\
\hline Spain & -1.99 & 265 & -3.28 & 210 & -1.50 & 150 & -0.75 & 72 & -7.52 & 697 \\
\hline Sweden & -0.59 & 105 & -0.94 & 83 & -0.43 & 60 & -0.22 & 29 & -2.17 & 277 \\
\hline UK & -1.83 & 319 & -2.94 & 252 & -1.34 & 181 & -0.68 & 88 & -6.79 & 840 \\
\hline \multicolumn{11}{|c|}{ Estimates for European Union countries where IMS data is not available } \\
\hline Cyprus & -0.04 & 5 & -0.07 & 4 & -0.03 & 3 & -0.02 & 1 & -0.16 & 13 \\
\hline Denmark & -0.60 & 61 & -0.96 & 48 & -0.44 & 35 & -0.22 & 17 & -2.21 & 161 \\
\hline Estonia & -0.04 & 5 & -0.07 & 4 & -0.03 & 3 & -0.02 & 1 & -0.16 & 13 \\
\hline Greece & -0.36 & 62 & -0.58 & 49 & -0.27 & 35 & -0.13 & 17 & -1.35 & 163 \\
\hline Latvia & -0.05 & 7 & -0.07 & 6 & -0.03 & 4 & -0.02 & 2 & -0.17 & 19 \\
\hline Lithuania & -0.10 & 11 & -0.17 & 8 & -0.08 & 6 & -0.04 & 3 & -0.39 & 28 \\
\hline Luxembourg & -0.02 & 3 & -0.03 & 3 & -0.02 & 2 & -0.01 & 1 & -0.08 & 9 \\
\hline
\end{tabular}


Table 3 continued

\begin{tabular}{|c|c|c|c|c|c|c|c|c|c|c|}
\hline & \multicolumn{2}{|l|}{ RA } & \multicolumn{2}{|l|}{$\mathrm{NHL}^{\mathrm{a}}$} & \multicolumn{2}{|l|}{ CLL } & \multicolumn{2}{|c|}{$\begin{array}{l}\text { Other indications } \\
\text { and off-label use }\end{array}$} & \multicolumn{2}{|l|}{ Total $^{\mathrm{c}}$} \\
\hline & $\begin{array}{l}\text { Budget } \\
\text { impact, } \\
\text { million } \\
\text { EUR }\end{array}$ & $\begin{array}{l}\text { No. of } \\
\text { patients }\end{array}$ & $\begin{array}{l}\text { Budget } \\
\text { impact, } \\
\text { million } \\
\text { EUR }\end{array}$ & $\begin{array}{l}\text { No. of } \\
\text { patients }\end{array}$ & $\begin{array}{l}\text { Budget } \\
\text { impact, } \\
\text { million } \\
\text { EUR }\end{array}$ & $\begin{array}{l}\text { No. of } \\
\text { patients }\end{array}$ & $\begin{array}{l}\text { Budget } \\
\text { impact, } \\
\text { million } \\
\text { EUR }\end{array}$ & $\begin{array}{l}\text { No. of } \\
\text { patients }\end{array}$ & $\begin{array}{l}\text { Budget } \\
\text { impact, } \\
\text { million } \\
\text { EUR }\end{array}$ & $\begin{array}{l}\text { No. of } \\
\text { patients }\end{array}$ \\
\hline Malta & -0.02 & 2 & -0.04 & 2 & -0.02 & 1 & -0.01 & 1 & -0.08 & 6 \\
\hline Total $^{\mathrm{c}}$ & -24.22 & 2857 & -39.02 & 2263 & -17.80 & 1624 & -9.00 & 787 & -90.04 & 7531 \\
\hline
\end{tabular}

Number of additional patients that could access rituximab treatment if all projected budget savings from the introduction of CT-P10 were allocated to this. Base case scenario assumed CT-P10 uptake of $30 \%$ and that the cost of CT-P10 was $70 \%$ of the cost of reference rituximab

$C L L$ chronic lymphocytic leukemia, NHL non-Hodgkin's lymphoma, $R A$ rheumatoid arthritis

a NHL comprised diffuse large B cell lymphoma and stage III-IV follicular lymphoma

b Granulomatosis with polyangiitis (formerly Wegener's granulomatosis) and microscopic polyangiitis

c Total values may differ slightly from the sum of individual values, due to rounding

patients with NHL, 1624 patients with CLL, and 787 patients with other diagnoses; Table 3). This was equivalent to a $6.4 \%$ increase in the number of rituximab-treated patients. The country-level distribution of the budget savings and additional number of patients that could be treated are shown in Table 3.

A second scenario was also modeled, in which the market share of CT-P10 was assumed to be $50 \%$ (scenario 2). In this case, the total projected budget saving in Europe was $€ 150.10$ million, which would allow access to rituximab treatment for 12,551 additional patients $(4762$ with RA, 3771 with NHL, 2706 with CLL, and 1312 with other diagnoses; Supplementary Table S3). This corresponded to a $10.7 \%$ total increase in the number of rituximab-treated patients.

\section{Three-year Time Horizon}

Three-year time horizon outcomes were also modeled (Supplementary Table S4), in which the market share of CT-P10 was assumed to be $30 \%$ in the first year, $40 \%$ in the second year, and $50 \%$ in the third year. Over this 3-year period budget savings across Europe would be approximately $€ 570$ million, equating to 47,695 additional patients accessing rituximab treatment.

\section{Sensitivity Analyses}

One-way sensitivity analyses demonstrated a linear relationship between uptake and budget savings (i.e., doubling the uptake from $25 \%$ to $50 \%$ would double the savings). Linear relationships were also observed in the case of the other parameters tested. BSA changes had insignificant effects. The price of CT-P10 and the market share were found to have a major impact on model results.

\section{DISCUSSION}

Our BIA model demonstrated that introduction of the rituximab biosimilar CT-P10 into the EU would save $€ 90.04$ million in the first year (assuming 30\% market share), which could be reallocated to allow 7531 additional patients (including 2857 patients with RA, 2263 patients with NHL, 1624 patients with CLL, and 787 patients with other diagnoses) to access rituximab treatment. This was equivalent to a $6.4 \%$ increase in patients with access to rituximab. If CT-P10 market share was assumed to be 50\%, budget savings rise to $€ 150.10$, with a total of 12,551 additional patients now able to access rituximab. Over a 3-year time horizon, projected budget savings total approximately $€ 570$ 
million, equating to 47,695 additional patients able to access this potentially life-changing treatment. These data clearly represent a substantial societal health gain and it can be concluded from our findings that, with some assumptions as defined in the model, use of CT-P10 will present significant savings for healthcare systems, in accordance with our stated hypothesis. Although we assumed the price of CT-P10 to be up to 30\% lower than that of RTX, expert opinion suggests that the actual difference could be as much as $60-70 \%$. Thus, our projections on the number of additional patients able to access treatment might be considered conservative estimates, and actual figures may prove to be notably higher.

As with all BIA models, assumptions were applied that create some uncertainty with respect to the inputted data. For example, as a result of a lack of literature evidence, we estimated the number of RTX-treated patients from IMS utilization data. We also applied some estimates to the calculation of RTX distribution across diagnoses, again because of a lack of literature data. Finally, list prices may differ from actual purchasing prices (which are not publicly available), and an assumption was made with respect to the price of CT-P10 as a proportion of RTX list price. Several other factors outside the scope of this model may influence the budget impact of CT-P10, such as the emergence of other biosimilars and originator products, and price reductions of the reference product. However, no other rituximab biosimilars are currently available for use in the indications assessed in this study, and new originator biologicals are either under regulatory review or only recently approved. Given the time horizon of our model these factors, and potential RTX price reductions, are unlikely to impact our findings.

In addition to these methodological limitations, it should be remembered that inequities in access to rituximab are not solely linked to national income [28, 57]; for example, countryand healthcare system-specific factors also influence uptake of biosimilars [58-60]. It is important to understand that the availability of CT-P10 at a lower cost than RTX will not in itself automatically increase patient access to rituximab. Payer, healthcare professional, and patient perceptions regarding the use of biosimilars also play an important role in determining uptake.

There are two broad potential patient populations who may be treated with CT-P10: RTX-naïve patients and those already receiving RTX who could be switched to CT-P10. The clinical uptake of CT-P10 will therefore be dependent on both these populations. Clinical evidence from other EMA-approved second-generation biosimilars suggests that switching does not result in decreased efficacy or new safety concerns. For example, a large phase 4 randomized controlled trial funded by the Norwegian government (NOR-SWITCH) assessed the switch from reference infliximab to CT-P13 in six immune-mediated inflammatory diseases including RA [61] and found that switching to the biosimilar was not inferior to continued treatment with the reference product [62]. However, physicians may have reservations regarding switching to a biosimilar and, in general, seem to be less willing to switch patients already receiving treatment with an innovator or reference product than to prescribe a biosimilar to a biological-naïve patient [63]. This "ambiguity or uncertainty aversion" may be reduced when healthcare professionals are able to reallocate budget themselves [64]. Healthcare professionals may choose, for example, to use financial savings to enable more patients to access treatment, for patients to access treatment at an earlier stage of disease, or to benefit patients being treated for other diseases.

Uptake of biosimilars may also be affected by physician views on the process of "extrapolation". The EMA and US Food and Drug Administration consider that once a biosimilar demonstrates comparability to its reference product in one indication, extrapolation of data can permit approval in other indications held by the reference product, as long as this is scientifically justified $[4,65]$. For example, use of biosimilar epoetins in chemotherapy-induced anemia was originally permitted owing in part to extrapolation from studies in renal anemia $[66,67]$. Despite the stringent regulatory requirements for extrapolation, concern can 
still exist among physicians regarding this process, as was initially the case for some inflammatory bowel disease (IBD) specialists after approval of CT-P13 in IBD [68]. In the case of CT-P13 (clinical trials of which were performed in RA and ankylosing spondylitis), initial concerns about extrapolation centered around possible differences in the mechanisms of action of infliximab in IBD versus rheumatology indications, although these were subsequently proved unfounded [69]. Post-approval data on the real-world use of CT-P13 in IBD has since provided reassurance on its efficacy and safety in this setting, as evidenced in a recent statement from the European Crohn's and Colitis Organisation which asserts that switching from an originator or reference product to a biosimilar in IBD patients is acceptable [70]. In line with regulatory requirements, approval of CT-P10 in some indications of RTX was based in part on the extrapolation of clinical data collected in other indications [36-45], plus a scientific justification based on the consistency of rituximab mechanisms of action across indications.

BIA analyses are limited in the literature, both in general [34] and with respect to second-generation biosimilars [12]; therefore, the present study represents a valuable addition to the current knowledge base. In 2014, a systematic literature review identified a total of $17 \mathrm{EU}$ BIA publications across all therapy areas [71]. A 2015 review [12] of the budget impact of the introduction of biosimilars in rheumatology found three BIA studies [72-74], two studies that reported data in six indications (RA, psoriatic arthritis, ankylosing spondylitis, Crohn's disease, ulcerative colitis, and psoriasis) $[75,76]$, and a further two studies in IBD [77, 78]. To our knowledge, a further two studies have estimated the potential cost savings of biosimilar infliximab in IBD and of biosimilar etanercept in all indications $[79,80]$. Thus there are a total of nine BIA studies of second-generation biosimilars in rheumatology, gastroenterology, and dermatology, with substantial budget savings presented in all papers [72-80]. For example, the introduction of CT-P13 in Central and Eastern Europe was estimated to result in $€ 15.3-20.8$ million budget savings over 3 years in RA, enabling 1200-1800 extra patients to be treated [73], and savings of $€ 8.0-16.9$ million in Crohn's disease, enabling 722-1530 extra patients to be treated [77]. Annual savings in the treatment of inflammatory autoimmune diseases in Belgium, Germany, the Netherlands, and the UK and due to CT-P13 were estimated to be $€ 2.89-33.80$ million, enabling 250-2602 additional patients to be treated [76]. Predicted savings with CT-P13 over 5 years in RA in France, Germany, Italy, and the UK totaled €96-433 million [72]. Savings were also predicted with the introduction of an etanercept biosimilar in the treatment of inflammatory autoimmune diseases in France Germany, Italy, Spain, and the UK. Over 5 years, these savings totaled $€ 35-284$ million, resulting in an additional $3100-17,130$ patients able to access treatment [80]. In the area of supportive cancer care, budget impact and cost-effectiveness analyses of first-generation biosimilars in supportive care have also demonstrated the cost savings of biosimilars. For example, a BIA model of biosimilar erythropoiesis-stimulating agent usage in the EU G5 (France, Germany, Italy, Spain, and UK) calculated that $€ 111-146$ million could be saved if all patients converted to biosimilar erythropoiesis-stimulating agent, potentially freeing up budget from supportive care for reallocation to increase patient access to anticancer treatments [81]. Analyses in the EU G5 illustrate cost savings associated with biosimilar filgrastim, estimated at between $€ 32.70$ (1-day regimen) to $€ 2747$ (14-day regimen) per treatment, compared with the reference product $[82,83]$.

Realizing the benefits of biosimilars in clinical practice is a major challenge for the coming years. For RTX biosimilars, the most evident benefit is the potential to cut the ever-growing healthcare costs associated with the treatment of RA and cancer and thus potentially help to maintain or increase patient access. The budget savings achieved via the use of biosimilars can be reinvested into the treatment of additional patients, as proposed in our study (Table 3) and two multi-country BIAs $[76,77]$. In this respect, some countries have already demonstrated an intention to benefit from using biosimilars in their healthcare system. The lower cost of 
CT-P13 has driven uptake in Europe, with market share reaching $73 \%$ in the UK by mid-2016 [84]. In South Korea, 15 months from the introduction of biosimilar infliximab, approximately $20 \%$ of all patients treated with infliximab received the biosimilar. At the same time, the use of biological therapy increased [85]. Such findings provide real-world evidence that budget savings are being spent on the reimbursement of biosimilar therapy for additional patients.

Aggregated health gains at a societal level can also be estimated in terms of quality-adjusted life year (QALY) gains. In virtually all European countries, health technology assessment guidelines require the reporting of QALY gains at a patient and societal level, as well as cost-effectiveness and budget impact. These data form part of a product's economic dossier and are required by public bodies for reimbursement. In this study, we report BIA data. By comparing our data on the numbers of additional patients that could access treatment as a result of budget savings to literature data on the relationship between numbers of additional patients and associated average QALY gains, estimates of expected QALY gains due to the introduction of CT-P10 can be made (assuming budget savings are reallocated to treat new patients within the same diagnosis). As calculated QALY gains are based on patient-reported outcome measures, such as the EQ-5D questionnaire [86, 87], this measure gives some indication of patient-level health gains, and is of increasing importance in determining the overall value of a therapeutic intervention.

Some evidence already exists regarding QALY gains with the use of biological therapies, including RTX. In RA, the mean QALY gain during 1 year of biological therapy is 0.14 [88]. In DLBCL, various groups report that R-CHOP (rituximab with cyclophosphamide, doxorubicin, vincristine, and prednisone) results in a QALY gain of between 0.82 and 1.07 QALYs compared with CHOP alone, over a 15-year time horizon [89-91]. In CLL, when RTX is added to fludarabine and cyclophosphamide (FC), QALYs increase to 1.127 (assuming an effect for 5.9 years) and to 1.459 (assuming an effect for 10 years) compared with FC alone [92]. Another study found the addition of RTX to FC led to an incremental gain of 0.94 QALYs in a 15-year horizon [93]. In a lifetime horizon study in advanced FL, the addition of RTX to chemotherapy increased QALY by $0.458-1.184$ $[94,95]$. Wisløff et al. recently conducted a review of cost-utility studies and evaluated expected incremental QALY gains [87]. In the 333 studies identified, the median incremental QALY gain across a range of indications was 0.06 . The authors noted a number of methodological limitations that affected the determination of QALY gains in individual studies. Using the data collected in the present study, the projected societal QALY gains for RA in the EU are 400 and 667 QALYs per year in the base case scenario and scenario 2 , respectively. In NHL, the QALY gain is estimated at 133 in the base case scenario and 221 in scenario 2, while in CLL the QALY gain per year would be 95-310 and 159-517 in the base case scenario and scenario 2 , respectively.

\section{CONCLUSIONS}

The introduction of the rituximab biosimilar CT-P10 in the EU is expected to be associated with significant budget savings. Reallocation of these savings to the treatment of additional patients will increase access to rituximab treatment, enabling many more patients with RA, NHL, and CLL to be treated. This is likely to have a significant impact on health gains at both patient and societal levels.

\section{ACKNOWLEDGEMENTS}

CELLTRION Healthcare Co., Ltd. (Incheon, Republic of Korea) sponsored the development and analysis of the CT-P10 budget impact model and funded the journal's processing fees for this article. The authors did not receive payment or any kind of benefit from CELLTRION for their contribution to this paper.

Medical writing support was provided by Hannah Mace, MPharmacol. at Aspire Scientific Limited (Bollington, UK) and was funded by CELLTRION Healthcare Co., Ltd. (Incheon, Republic of Korea). 
All authors had full access to all of the data in this study and take complete responsibility for the integrity of the data and accuracy of the data analysis. All named authors meet the International Committee of Medical Journal Editors (ICMJE) criteria for authorship for this manuscript, take responsibility for the integrity of the work as a whole, and have given final approval for the version to be published.

Disclosures. László Gulácsi, Valentin Brodszky, and Petra Baji have been paid as consultants and received funding and support for research on biosimilars from CELLTRION Healthcare, EGIS Pharma and Hospira Pfizer. Fanni Rencz has been paid as a consultant for research on biosimilars by CELLTRION Healthcare. Márta Péntek has been paid as a consultant and received funding and support for research on biosimilars from CELLTRION Healthcare, EGIS Pharma, Hospira Pfizer, and Merck.

Compliance with Ethics Guidelines. This article does not contain any new studies with human or animal subjects performed by any of the authors.

Data Availability. All data generated or analyzed during this study are included in this published article/as supplementary information files.

Open Access. This article is distributed under the terms of the Creative Commons Attribution-NonCommercial 4.0 International License (http://creativecommons.org/licenses/ by-nc/4.0/), which permits any noncommercial use, distribution, and reproduction in any medium, provided you give appropriate credit to the original author(s) and the source, provide a link to the Creative Commons license, and indicate if changes were made.

\section{REFERENCES}

1. Roche Pharma AG. Summary of product characteristics. Mabthera $100 \mathrm{mg}$ concentrate for solution for infusion. 2016. http://www.ema.europa.eu/
docs/en_GB/document_library/EPAR_-_Product_ Information/human/000165/WC500025821.pdf. Accessed 23 Feb 2017.

2. Genentech, Inc. Rituxan (rituximab) prescribing information. 2010. http://www.accessdata.fda. gov/drugsatfda_docs/label/2010/103705s5311lbl.pdf. Accessed 23 Feb 2017.

3. Generics and Biosimilars Initiative Online. EMA approval for rituximab biosimilar Truxima. 2017. http://www.gabionline.net/Biosimilars/News/EMAapproval-for-rituximab-biosimilar-Truxima. Accessed 23 Feb 2017.

4. European Medicines Agency. Guideline on similar biological medicinal products containing biotechnology-derived proteins as active substance: nonclinical and clinical issues. 2014. http://www.ema. europa.eu/docs/en_GB/document_library/Scientific_ guideline/2015/01/WC500180219.pdf. Accessed 23 Feb 2017.

5. Schellekens H, Smolen JS, Dicato M, Rifkin RM. Safety and efficacy of biosimilars in oncology. Lancet Oncol. 2016;17:e502-9.

6. Generics and Biosimilars Initiative Online. Biosimilars approved in Europe. 2017. http://www.gabi online.net/Biosimilars/General/Biosimilars-approvedin-Europe. Accessed 23 Feb 2017.

7. Zarkali A, Karageorgopoulos DE, Rafailidis PI, Falagas ME. Frequency of the off-label use of monoclonal antibodies in clinical practice: a systematic review of the literature. Curr Med Res Opin. 2014;30:471-80.

8. Bourdette D. Rituximab for treating multiple sclerosis: off-label but on target. Neurology. 2016;87:2070-1.

9. Castillo-Trivino T, Braithwaite D, Bacchetti P, Waubant E. Rituximab in relapsing and progressive forms of multiple sclerosis: a systematic review. PLoS One. 2013;8:e66308.

10. Ryden-Aulin M, Boumpas D, Bultink I, et al. Off-label use of rituximab for systemic lupus erythematosus in Europe. Lupus Sci Med. 2016;3:e000163.

11. Collongues N, de Seze J. An update on the evidence for the efficacy and safety of rituximab in the management of neuromyelitis optica. Ther Adv Neurol Disord. 2016;9:180-8.

12. Gulacsi L, Brodszky V, Baji P, et al. Biosimilars for the management of rheumatoid arthritis: economic considerations. Expert Rev Clin Immunol. 2015;11(Suppl 1):S43-52. 
13. National Institute for Health and Care Excellence. Rheumatoid arthritis in adults: National clinical guideline for management and treatment in adults. Clinical guideline [CG79]. 2009. https://www.nice. org.uk/guidance/cg79/evidence/full-guideline-2421 91261. Accessed 23 Feb 2017.

14. Cross M, Smith E, Hoy D, et al. The global burden of rheumatoid arthritis: estimates from the global burden of disease 2010 study. Ann Rheum Dis. 2014;73:1316-22.

15. Global Burden of Disease Cancer Collaboration. Global, regional, and national cancer incidence, mortality, years of life lost, years lived with disability, and disability-adjusted life-years for 32 cancer groups, 1990 to 2015: a systematic analysis for the global burden of disease study. JAMA Oncol. 2016. doi:10.1001/jamaoncol.2016.5688

16. Sant M, Minicozzi P, Mounier M, et al. Survival for haematological malignancies in Europe between 1997 and 2008 by region and age: results of EUROCARE-5, a population-based study. Lancet Oncol. 2014;15:931-42.

17. Eichhorst B, Robak T, Montserrat E, et al. Chronic lymphocytic leukaemia: ESMO clinical practice guidelines for diagnosis, treatment and follow-up. Ann Oncol. 2015;26(Suppl 5):v78-84.

18. Cancer Research UK. Chronic lymphocytic leukaemia (CLL) incidence statistics. 2014. http://www. cancerresearchuk.org/health-professional/cancerstatistics/statistics-by-cancer-type/leukaemia-cll/inci dence. Accessed 27 Jan 2017.

19. Keating GM. Rituximab: a review of its use in chronic lymphocytic leukaemia, low-grade or follicular lymphoma and diffuse large B-cell lymphoma. Drugs. 2010;70:1445-76.

20. Dotan E, Aggarwal C, Smith MR. Impact of rituximab (rituxan) on the treatment of B-cell non-Hodgkin's lymphoma. Pharma Ther. 2010;35:148-57.

21. Smolen JS, Landewe R, Breedveld FC, et al. EULAR recommendations for the management of rheumatoid arthritis with synthetic and biological disease-modifying antirheumatic drugs: 2013 update. Ann Rheum Dis. 2014;73:492-509.

22. National Institute for Health and Care Excellence. Rituximab for the first-line treatment of chronic lymphocytic leukaemia. Technology appraisal guidance [TA174]. 2009. https://www.nice.org.uk/ guidance/ta174. Accessed 23 Feb 2017.

23. National Institute for Health and Care Excellence. Rituximab for the treatment of relapsed or refractory chronic lymphocytic leukaemia. Technology appraisal guidance [TA193]. 2010. https://www. nice.org.uk/guidance/ta193. Accessed 23 Feb 2017.

24. National Institute for Health and Care Excellence. Rituximab for the first-line maintenance treatment of follicular non-Hodgkin's lymphoma. Technology appraisal guidance [TA226]. 2011. https://www. nice.org.uk/guidance/ta226. Accessed 23 Feb 2017.

25. National Institute for Health and Care Excellence. Rituximab for the first-line treatment of stage III-IV follicular lymphoma. Technology appraisal guidance [TA243]. 2012. https://www.nice.org.uk/ guidance/ta243. Accessed 23 Feb 2017.

26. National Institute for Health and Care Excellence. Non-Hodgkin's lymphoma: diagnosis and management. NICE guideline [NG52]. 2016. https://www. nice.org.uk/guidance/ng52. Accessed 23 Feb 2017.

27. Hoebert JM, Mantel-Teeuwisse AK, van Dijk L, Bijlsma JW, Leufkens HG. Do rheumatoid arthritis patients have equal access to treatment with new medicines? Tumour necrosis factor-alpha inhibitors use in four European countries. Health Policy. 2012;104:76-83.

28. Putrik P, Ramiro S, Kvien TK, et al. Inequities in access to biologic and synthetic DMARDs across 46 European countries. Ann Rheum Dis. 2014;73:198-206.

29. Baer Ii WH, Maini A, Jacobs I. Barriers to the access and use of rituximab in patients with non-hodgkin's lymphoma and chronic lymphocytic leukemia: a physician survey. Pharmaceuticals (Basel). 2014;7:530-44.

30. Boncz I, Sebestyen A. Financial deficits in the health services of the UK and Hungary. Lancet. 2006;368:917-8.

31. Tabernero J, Vyas M, Giuliani R, et al. Biosimilars: a position paper of the European Society for Medical Oncology, with particular reference to oncology prescribers. ESMO Open. 2017;1:e000142.

32. Remuzat C, Urbinati D, Kornfeld A, et al. Pharmaceutical expenditure forecast model to support health policy decision making. J Mark Access Health Policy. 2014;2:23740. doi:10.3402/jmahp. v2.23740.

33. Urbinati D, Remuzat C, Kornfeld A, et al. EU pharmaceutical expenditure forecast. J Mark Access Health Policy. 2014:2. doi:10.3402/jmahp.v2.23738

34. Orlewska E, Gulacsi L. Budget-impact analyses: a critical review of published studies. Pharmacoeconomics. 2009;27:807-27.

35. Sullivan SD, Mauskopf JA, Augustovski F, et al. Budget impact analysis-principles of good practice: 
report of the ISPOR 2012 Budget Impact Analysis Good Practice II Task Force. Value Health. 2014;17:5-14.

36. Park W, Yoo DH, Suh CH, et al. Comparable time to retreatment with CT-P10 and innovator rituximab up to 2 years in patients with active rheumatoid arthritis [abstract no. THU0162]. Ann Rheum Dis. 2016;75(suppl 2):241-2.

37. Suh CH, Berrocal Kasay A, Chalouhi El-Khouri E, et al. Pharmacokinetics and safety of three formulations of rituximab (CT-P10, US-sourced innovator rituximab and EU-sourced innovator rituximab) in patients with rheumatoid arthritis: results from phase 3 randomized controlled trial over 24 weeks [abstract]. Arthritis Rheumatol. 2016;68:1634.

38. Yoo DH, Bozic Majstorovic L, Berrocal Kasay A, et al. Efficacy and safety of CT-P10, rituximab biosimilar candidate, and innovator rituximab in patients with rheumatoid arthritis: results from phase 3 randomized controlled trial over 24 weeks [abstract]. Arthritis Rheumatol. 2016;68:1635.

39. Yoo DH, Park W, Suh CH, et al. Efficacy and safety of switched CT-P10 from innovator rituximab compared to those of maintained CT-P10 in patients with rheumatoid arthritis up to 56 weeks [abstract]. Arthritis Rheumatol. 2015; 67. 2015;67:1675.

40. Yoo DH, Park W, Suh CH, et al. Efficacy and safety of rituximab biosimilar candidate (CT-P10) and innovator rituximab in patients with rheumatoid arthritis: results from phase I randomized controlled trial over 72 weeks [abstract]. Arthritis Rheumatol. 2015;67:2058.

41. Yoo DH, Suh C, Shim SC, et al. A multicentre randomised controlled trial to compare the pharmacokinetics, efficacy and safety of CT-P10 and innovator rituximab in patients with rheumatoid arthritis. Ann Rheum Dis. 2017;76:556-70.

42. Yoo D-H, Park W, Jeka S, et al. A randomized, controlled, multicenter, 2-arm, parallel-group, double-blind study to demonstrate the equivalence of CT-P10 to innovator rituximab with respect to pharmacokinetic profile in patients with rheumatoid arthritis [abstract]. Arthritis Rheumatol. 2013;65:1736.

43. Yoo D-H, Park W, Jeka S, et al. Impact of anti-drug antibody on efficacy and safety over week 24 in both CT-P10 and innovator rituximab treatment groups [abstract 1508]. Arthritis Rheumatol. 2014;66:S663-4.

44. Coiffier B, Sancho J-M, Jurczak W, et al. 1807 Pharmacokinetic and safety of CT-P10, a biosimilar candidate to the rituximab reference product, in patients with newly diagnosed advanced stage follicular lymphoma (AFL). American Society of Hematology, 2016.

45. Kim WS, Ogura M, Buske C, et al. Global phase I/III pharmacokinetic and efficacy study comparing CT-P10, a biosimilar candidate to the rituximab reference product in patients with advanced stage follicular lymphoma (AFL). Blood. 2015;126:5111.

46. Roche. Finance report 2015. 2015. http://www. roche.com/dam/jcr:74af99eb-b51a-4f13-88b2-aaca f9f53c0c/en/fb15e.pdf. Accessed 23 Feb 2017.

47. Sant M, Allemani C, Tereanu C, et al. Incidence of hematologic malignancies in Europe by morphologic subtype: results of the HAEMACARE project. Blood. 2010;116:3724-34.

48. Gang AO, Pedersen M, d'Amore F, et al. A clinically based prognostic index for diffuse large B-cell lymphoma with a cut-off at 70 years of age significantly improves prognostic stratification: population-based analysis from the Danish Lymphoma Registry. Leuk Lymphoma. 2015;56:2556-62.

49. Issa DE, van de Schans SA, Chamuleau ME, et al. Trends in incidence, treatment and survival of aggressive B-cell lymphoma in the Netherlands 1989-2010. Haematologica. 2015;100:525-33.

50. Junlen HR, Peterson S, Kimby E, et al. Follicular lymphoma in Sweden: nationwide improved survival in the rituximab era, particularly in elderly women: a Swedish Lymphoma Registry study. Leukemia. 2015;29:668-76.

51. Knauf W, Abenhardt W, Dorfel S, et al. Routine treatment of patients with chronic lymphocytic leukaemia by office-based haematologists in Germany-data from the Prospective Tumour Registry Lymphatic Neoplasms. Hematol Oncol. 2015;33:15-22.

52. Marcus R, Imrie K, Solal-Celigny P, et al. Phase III study of R-CVP compared with cyclophosphamide, vincristine, and prednisone alone in patients with previously untreated advanced follicular lymphoma. J Clin Oncol. 2008;26:4579-86.

53. Ferrario A, Kanavos P. Managed entry agreements for pharmaceuticals: the European experience. 2013. http://eprints.lse.ac.uk/50513/. Accessed 23 Feb 2017.

54. Sacco JJ, Botten J, Macbeth F, Bagust A, Clark P. The average body surface area of adult cancer patients in the UK: a multicentre retrospective study. PLoS One. 2010;5:e8933.

55. Tilly H, Gomes da Silva M, Vitolo U, et al. Diffuse large B-cell lymphoma (DLBCL): ESMO Clinical 
Practice Guidelines for diagnosis, treatment and follow-up. Ann Oncol. 2015;26:v116-25.

56. Dreyling M, Ghielmini M, Rule S, Salles G, Vitolo U, Ladetto M. Newly diagnosed and relapsed follicular lymphoma: ESMO clinical practice guidelines for diagnosis, treatment and follow-up. Ann Oncol. 2016;27:v83-90.

57. Gulácsi L, Rencz F, Poór G, Szekanecz Z, Brodszky V, Baji P, Péntek M. Patients' access to biological therapy in chronic inflammatory conditions; per capita GDP does not explain the intercountry differences. Ann Rheum Dis. 2016;75(5):942-3.

58. Bocquet F, Loubiere A, Fusier I, Cordonnier AL, Paubel P. Competition between biosimilars and patented biologics: learning from European and Japanese experience. Pharmacoeconomics. 2016;34:1173-86.

59. Jahnsen J. Clinical experience with infliximab biosimilar Remsima (CT-P13) in inflammatory bowel disease patients. Therap Adv Gastroenterol. 2016;9:322-9.

60. Renwick MJ, Smolina K, Gladstone EJ, Weymann D, Morgan SG. Postmarket policy considerations for biosimilar oncology drugs. Lancet Oncol. 2016;17:e31-8.

61. ClinicalTrials.gov. The NOR-SWITCH Study (NOR-SWITCH). 2017. https://clinicaltrials.gov/ ct2/show/NCT02148640. Accessed 31 Jan 2017.

62. Goll GL, Olsen IC, Jorgensen KK, et al. Biosimilar infliximab (CT-P13) is not inferior to originator infliximab: results from a 52-week randomized switch trial in norway [abstract]. Arthritis Rheumatol. 2016;68:19L.

63. Baji P, Gulacsi L, Lovasz BD, et al. Treatment preferences of originator versus biosimilar drugs in Crohn's disease; discrete choice experiment among gastroenterologists. Scand J Gastroenterol. 2016;51:22-7.

64. Baji P, Gulacsi L, Golovics PA, et al. Perceived risks contra benefits of using biosimilar drugs in ulcerative colitis: discrete choice experiment among gastroenterologists. Value Health Reg Issues. 2016;10:85-90.

65. US Food and Drug Administration. Scientific considerations in demonstrating biosimilarity to a reference product. 2015. http://www.fda.gov/down loads/Drugs/GuidanceComplianceRegulatoryInfor mation/Guidances/UCM291128.pdf. Accessed 20 Jan 2017.

66. Jelkmann W. Biosimilar epoetins and other "follow-on" biologics: update on the European experiences. Am J Hematol. 2010;85:771-80.
67. Leung LK, Mok K, Liu C, Chan SL. What do oncologists need to know about biosimilar products? Chin J Cancer. 2016;35:91.

68. Reinisch W, Louis E, Danese S. The scientific and regulatory rationale for indication extrapolation: a case study based on the infliximab biosimilar CT-P13. Expert Rev Gastroenterol Hepatol. 2015;9(Suppl 1):17-26.

69. Ben-Horin S, Vande Casteele N, Schreiber S, Lakatos PL. Biosimilars in inflammatory bowel disease: facts and fears of extrapolation. Clin Gastroenterol Hepatol. 2016;14:1685-96.

70. Danese S, Fiorino G, Raine T, et al. ECCO position statement on the use of biosimilars for inflammatory bowel disease-an update. J Crohns Colitis. 2017;11:26-34.

71. van de Vooren K, Duranti S, Curto A, Garattini L. A critical systematic review of budget impact analyses on drugs in the EU countries. Appl Health Econ Health Policy. 2014;12:33-40.

72. Kim J, Hong J, Kudrin A. 5 year budget impact analysis of biosimilar infliximab for the treatment of rheumatoid arthritis in UK, Italy, France and Germany. Arthritis Rheumatol. 2014;11:S512.

73. Brodszky V, Baji P, Balogh O, Pentek M. Budget impact analysis of biosimilar infliximab (CT-P13) for the treatment of rheumatoid arthritis in six Central and Eastern European countries. Eur J Health Econ. 2014;15(Suppl 1):S65-71.

74. McCarthy G, Bitoun CE, Guy H. Introduction of an infliximab biosimilar (CT-P13): a five-year budget impact analysis for the treatment of rheumatoid arthritis in Ireland. Value Health. 2013;16:A558.

75. Lucioni C, Mazzi S, Caporali R. Budget impact analysis of infliximab biosimilar: the Italian scenery. GRHTA. 2015;2:78-88.

76. Jha A, Upton A, Dunlop WC, Akehurst R. The budget impact of biosimilar infliximab (Remsima $\left.{ }^{\circledR}\right)$ for the treatment of autoimmune diseases in five European countries. Adv Ther. 2015;32:742-56.

77. Brodszky V, Rencz F, Pentek M, Baji P, Lakatos PL, Gulacsi L. A budget impact model for biosimilar infliximab in Crohn's disease in Bulgaria, the Czech Republic, Hungary, Poland, Romania, and Slovakia. Expert Rev Pharmacoecon Outcomes Res. 2016;16:119-25.

78. Kim JAHJ, Kudrin A. 5 year budget impact analysis of CT-P13 (infliximab) for the treatment of Crohn's disease in UK, Italy and France. J Crohns Colitis. 2015;9(S144):137. 
79. Severs M, Oldenburg B, van Bodegraven AA, Siersema PD, Mangen MJ. The economic impact of the introduction of biosimilars in inflammatory bowel disease. J Crohns Colitis. 2017;11:289-96.

80. Ruff L, Rezk MF, Uhlig T, Gommers JW. Budget impact analysis of an etanercept biosimilar for the treatment of all licensed etanercept indications for adults in Europe. Value Health. 2015;18:A639.

81. Abraham I, Han L, Sun D, MacDonald K, Aapro M. Cost savings from anemia management with biosimilar epoetin alfa and increased access to targeted antineoplastic treatment: a simulation for the EU G5 countries. Future Oncol. 2014;10:1599-609.

82. Sun D, Andayani TM, Altyar A, MacDonald K, Abraham I. Potential cost savings from chemotherapy-induced febrile neutropenia with biosimilar filgrastim and expanded access to targeted antineoplastic treatment across the European Union G5 countries: a simulation study. Clin Ther. 2015;37:842-57.

83. Aapro M, Cornes P, Abraham I. Comparative cost-efficiency across the European G5 countries of various regimens of filgrastim, biosimilar filgrastim, and pegfilgrastim to reduce the incidence of chemotherapy-induced febrile neutropenia. J Oncol Pharm Pract. 2012;18:171-9.

84. Han S, Kim S, Kim J, et al. P582 The pharmacoeconomic impact of biosimilar infliximab (CT-P13) in Europe from January 2015 to June 2016. J Crohns Colitis. 2017;11(suppl 1):S377.

85. Kim SC, Choi NK, Lee J, et al. Brief report: utilization of the first biosimilar infliximab since its approval in South Korea. Arthritis Rheumatol. 2016;68:1076-9.

86. EuroQol Research Foundation. What is EQ-5D? 2017. http://www.euroqol.org/. Accessed 22 Feb 2017.

87. Wisløff T, Hagen G, Hamidi V, Movik E, Klemp M, Olsen JA. Estimating QALY gains in applied studies: a review of cost-utility analyses published in 2010 . Pharmacoeconomics. 2014;32:367-75.

88. Linde L, Sorensen J, Ostergaard M, Hetland ML. Gain in quality-adjusted life-years in patients with rheumatoid arthritis during 1 year of biological therapy: a prospective study in clinical practice. J Rheumatol. 2013;40:1479-86.

89. Best JH, Hornberger J, Proctor SJ, Omnes LF, Jost F. Cost-effectiveness analysis of rituximab combined with $\mathrm{CHOP}$ for treatment of diffuse large B-cell lymphoma. Value Health. 2005;8:462-70.

90. Groot MT, Lugtenburg PJ, Hornberger J, Huijgens PC, Uyl-de Groot CA. Cost-effectiveness of rituximab (MabThera) in diffuse large B-cell lymphoma in The Netherlands. Eur J Haematol. 2005;74:194-202.

91. Knight C, Hind D, Brewer N, Abbott V. Rituximab $\left(\right.$ MabThera ${ }^{\circledR}$ ) for aggressive non-Hodgkin's lymphoma: systematic review and economic evaluation. Health Technol Assess. 2004;8:1-82.

92. Muller D, Fischer K, Kaiser P, et al. Cost-effectiveness of rituximab in addition to fludarabine and cyclophosphamide (R-FC) for the first-line treatment of chronic lymphocytic leukemia. Leuk Lymphoma. 2016;57:1130-9.

93. Adena M, Houltram J, Mulligan SP, Todd C, Malanos G. Modelling the cost effectiveness of rituximab in chronic lymphocytic leukaemia in first-line therapy and following relapse. Pharmacoeconomics. 2014;32:193-207.

94. Ray JA, Carr E, Lewis G, Marcus R. An evaluation of the cost-effectiveness of rituximab in combination with chemotherapy for the first-line treatment of follicular non-Hodgkin's lymphoma in the UK. Value Health. 2010;13:346-57.

95. Pettengell R, Donatti C, Hoskin P, et al. The impact of follicular lymphoma on health-related quality of life. Ann Oncol. 2008;19:570-6. 